\title{
Theoretical and Spectroscopic investigations of conformations, rotational barriers and scaled vibrations of 2,3-dimethyl hexane
}

\author{
Aziz Aboulmouhajir ${ }^{1, *}$, Said Mouatarif ${ }^{1}$, Mohiéeddine Hachim ${ }^{1}$, Naoual El Hamdani ${ }^{2}$ and \\ Mostafa Chhiba $^{3}$ \\ ${ }^{1}$ Equipe de Modélisation Moléculaire et Spectroscopie E2MS, Faculté des sciences, \\ Université Chouaïb Doukkali, El Jadida, Maroc \\ ${ }^{2}$ Laboratoire de chimie bio-organique, Faculté des sciences, Université Chouaïb Doukkali, El Jadida, Maroc \\ ${ }^{3}$ Laboratoire Rayonnement, Matière et Instrumentation, Faculté des sciences et Techniques, \\ Université Hassan $1^{\text {er }}$, Settat, Maroc.
}

\begin{abstract}
The 2,3-dimethyl hexane conformational isomerism has been investigated in detail, based on $\mathrm{HF}$, Post-HF and DFT calculations at different basis set. The effect of size of basis, ZPE, thermal contributions, electronic correlation and optimization methods on the conformational stability was discussed. The rotational barriers from the most stable conformer to the lowest energy secondary conformers and their correspondent inversion barriers at both HF and MP2 methods using 6-31G* basis set have also been approached. A normal mode calculation of the most and less-stable conformers using a scaled ab initio force field in terms of nonredundant local symmetry coordinates have been made to elucidate the conformational dependence of the vibrational spectra.
\end{abstract}

Keywords: Ab initio; Functional density theory; Conformational isomerism; Vibrational spectra; normal modes calculation; Scaled ab initio local symmetry force field.

\section{Introduction}

Branched alkanes having a chain length exceeding 7 carbons are commonly found in conventional petroleum as hydrocarbon fuels and Fischer-Tropsch (FT) chemical reaction. Before studying the combustion of real fuels based on their oxidation under specific conditions of temperature and pression inside the combustion chamber, it's essential to locate the steric zones hindering the abstraction of the hydrogen radicals during the oxidation for isolated molecule. Such study can also be focused towards understanding the relationship of permeation and selectivity with structure of organic polymer membranes as well as copolymer network interaction ${ }^{1,2}$. Because of the rotational isomerism problem, manifested by flexible molecules such as dimethyl hexanes, it's necessary to identify the right computational method for modeling their conformations and reproducing their thermochemical and vibrational properties as sources of confirmation ${ }^{3,4}$. Further, a special interest is given to dimethyl hexanes conformational and vibrational analyses owing to their use for development of therapeutical macromolecules force fields.

*Corresponding author: Aziz Aboulmouhajir

Email address: aboulmouhajir@gmail.com

DOI: http://dx.doi.org/10.13171/mjc61/01701191705/aboulmouhajir
To the best of our knowledge, neither quantum chemical calculations, nor the vibrational analysis study of 2,3-dimethylhexane has been reported yet. This deficiency observed in the literature encouraged us to carry out a complete assignment of the observed rich infrared and Raman spectra of this molecule after determining the most stable conformer and the secondary ones.

We first considered the effect of the correction of the zero-point vibrational energy (ZPE) which is the vibrational energy at $0 \mathrm{k}$, and the thermal correction (CT) on the internal energy (E) of the calculated conformations. Second, we studied the sensitivity of the internal energy to the basis set taking into account the d polarization functions on carbon atoms without $\left(6-31 \mathrm{G}^{*}\right)$ and with $\mathrm{p}$ polarization on hydrogen atoms $\left(6-31 \mathrm{G}^{* *}\right)$, the optimization method (HF and MP2) and the electron correlation of DFT and Post-HF methods. The rotational barriers from the most stable conformer to the lowest energy secondary conformers and their correspondent inversion barriers at both HF and MP2 methods using 6-31G* basis set have also been approached.

On the other hand, as the relationship between a vibrational spectrum and the corresponding structure, is not direct, the GF empirical formalism of Wilson ${ }^{5,6}$ was used.

Received September $27^{\text {th }}, 2016$

Accepted December 30 ${ }^{\text {th }}, 2016$

Published January $18^{\text {th }}, 2017$ 
Moreover, the scaling of the ab initio force field and the optimization of its scale factors were performed in order to provide a good agreement between the calculated and observed frequencies. Indeed, the ab initio calculated frequencies are relatively larger than the corresponding experimental values. This is partly due to neglect of anharmonicity and partly of the approximative nature of quantum mechanical methods (degree of neglect of electron correlation and basis set truncation). A normal mode calculation of the most and less-stable conformers of 2,3-DMH using this force field in terms of non-redundant local symmetry coordinates has been made. Contrary to our approach where about fourteen scaling factors were used for matching the computed frequencies with experimental ones without taking into account the vibrational infrared and Raman intensities, recently, just one scaling factor is considered for the assignment, but largely facilitated by a substantial effort towards modeling the vibrational intensities ${ }^{7-9}$. After providing all computational details, the calculation results will be discussed explicitly.

\section{Computational details}

To understand the extension of basis set, the electron correlation and the optimization effects on the relative stability, we have performed the MP2, MP3 and MP4 (DQ) energy calculations at both HF and MP2 optimized geometry with different basis set. LDA level and various gradient correction schemes (B3P86, B3PW91, BLYP, B3LYP) were also carried out. Geometry optimizations at $\mathrm{HF} / 6$ 31G* and B3LYP/6-31G* were followed by frequencies calculations at the same levels to obtain ZPE and thermal contributions in the total internal energy $E_{\text {tot }}$, in addition to enthalpy $\mathrm{H}$ (no scaling vibrational frequencies was applied) knowing that ${ }^{10}$ :

$$
\begin{gathered}
E_{\text {tot }}=E+E_{\mathrm{ZPE}}+C T \\
C . T=N_{0} \sum_{i} \frac{h v_{i}}{\left[1-\exp \left(-\frac{h v_{i}}{k T}\right)\right]}+3 R T \\
\mathrm{E}_{\mathrm{ZPE}}=N_{0} \sum_{i} \frac{1}{2} h v_{i}
\end{gathered}
$$

where $\mathrm{N}$ is the Avogadro number, $\mathrm{R}$ the gas constant, and for one mole of an ideal gas:

$$
H=E+E_{Z P E}+N_{0} \sum_{i} \frac{h v_{i}}{\left[1-\exp \left(-\frac{h v_{i}}{k T}\right)\right]}+4 R T
$$

The carbon positions for each isomer are well known by evaluating the three central C-C bonds
$\tau_{1}=\mathrm{C} 1-\mathrm{C} 2-\mathrm{C} 3-\mathrm{C} 4, \tau_{2}=\mathrm{C} 2-\mathrm{C} 3-\mathrm{C} 4-\mathrm{C} 5$ and $\tau_{3}=\mathrm{C} 3-$ C4-C5-C6. The torsional angle $\tau_{1}$ is taken to be positive if, when looking from $\mathrm{C} 2$ along $\mathrm{C} 2-\mathrm{C} 3$ bond, $\mathrm{C} 4$ is in the clockwise sense with respect to $\mathrm{C} 1$. The initial configuration and backbone torsional angles, as well as the numbering of the carbon atoms, are shown in Fig.1. In order to explore widely the space of configurations and generate a maximum of combination of terminal group positions, we have assigned $180^{\circ},+60^{\circ}$ and $-60^{\circ}$ to each of $\tau_{1}, \tau_{2}$ and $\tau_{3}$. Each conformation among twenty seven possible conformations obtained was then optimized at HF/6-31G using the method of complete relaxation without any symmetry constraint.

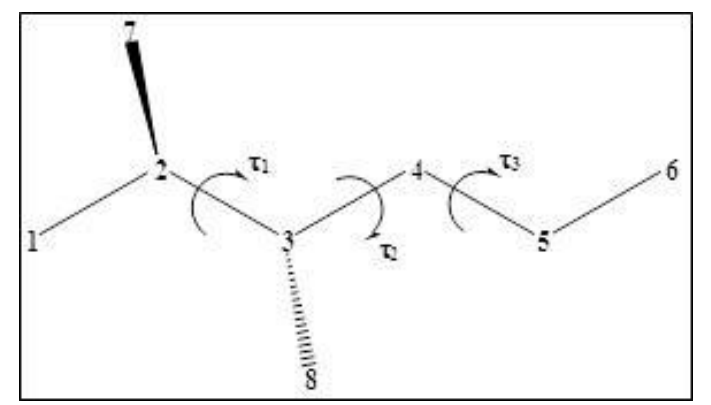

Figure 1. Numbering of the carbon atoms and definition of the torsional angles for 2,3-DMH

Normal mode calculations were carried out using the Wilson GF method. Force constants were obtained in Cartesian coordinates and transformed in term of non-redundant local symmetric coordinates in order to be transferred unchanged between conformers of each molecule. Indeed, the vibrational results of n-pentane and n-hexane obtained with these scale factors defined in terms of local symmetry coordinate (scale ab initio local symmetry force field SALSFF) were found slightly better than those obtained in terms of internal coordinates ${ }^{11}$. The complete force field in Cartesian coordinates was determined by ab initio molecular orbital calculations at HF/6-31G after optimizing the equilibrium geometries at the same level of theory. According to Mirkin and Krimm vibrational analysis on a series of n-alkanes and some branched alkanes (less than 6 carbons) ${ }^{11,12}$, it showed that HF/6-31G gives more accurate results (eigen vectors and interaction force constants) than $\mathrm{HF} / 6-31 \mathrm{G}^{*}$ and equivalent to MP2/6-31G*. All the above computations were performed using the Gaussian 2003 program package ${ }^{13}$, the program GAR2PED was used to obtain a potential energy distribution from a Gaussian archive record ${ }^{14}$.

\section{Results and discussion}

The 2,3-dimethyl hexane is the most rich molecule in the series of dimethyl hexanes in term of conformation. The most stable conformer $\mathrm{A}\left(\tau_{1}=68, \tau_{2}=163, \tau_{3}=-176\right) \quad(\mathrm{HF} / 6-31 \mathrm{G} \quad$ optimized geometry) has a six carbons chain in trans 
configuration ramified by two adjacent methyl groups on the same side as presented in Fig. 2. The same figure shows also all 3D secondary conformers with their Newman projections within a relative internal energy range of $1 \mathrm{kcal} / \mathrm{mol}$, which are:

$\mathrm{B}\left(\tau_{1}=-70, \tau_{2}=163, \tau_{3}=-177\right), \quad \mathrm{C}\left(\tau_{1}=64, \tau_{2}=58, \tau_{3}=172\right)$, $\mathrm{D}\left(\tau_{1}=167, \tau_{2}=159, \tau_{3}=180\right)$ and $\mathrm{E}\left(\tau_{1}=-176, \tau_{2}=-61\right.$, $\tau 3=-178)$. The two conformers $\mathrm{B}$ and $\mathrm{C}$ are very close to A (difference of about $0.2 \mathrm{kcal} / \mathrm{mol}$ ). Another group of conformers with extremely close energies contains $\mathrm{D}$ and $\mathrm{E}$ conformers while the relative energies of conformations destabilized by Syn-pentane interaction ${ }^{15}$ exceed $1.8 \mathrm{kcal} / \mathrm{mol}$. It should be noted that the conformer $\mathrm{D}$ is less stable than conformer A, even both branching methyls are not on the same side with respect to the trans main chain.

Regarding ZPE, thermal contribution to internal energy and enthalpic energy, they have an effect barely perceptible on the $\mathrm{HF} / 6-31 \mathrm{G}^{*}$ conformational stability ordering and no effect on B3LYP/6-31G* one ${ }^{16}$ (Tab. 1). Furthermore, the correlation of the relative energies of 2,3- DMH conformers obtained at various methods using different basis sets are discussed in more detail in Figure 3, Tab. 2 and Tab. 3 collected the post-HF and DFT results only at $6-31 \mathrm{G}^{* *}$.

Table 1. ZPE and thermal contribution in relative energies and relative enthalpies $(\mathrm{kcal} / \mathrm{mol})$ for 2,3-DMH conformers calculated with HF and B3LYP/6-31G* methods.

\begin{tabular}{|c|c|c|c|c|c|c|}
\hline \multirow[b]{2}{*}{ Conf. } & \multicolumn{3}{|c|}{ HF/6-31G* } & \multicolumn{3}{|c|}{ B3LYP/6-31G* } \\
\hline & $\Delta \mathbf{E}$ & $\Delta(\mathbf{E}+\mathrm{ZPE})$ & $\Delta \mathbf{H}$ & $\Delta \mathbf{E}$ & $\Delta(\mathbf{E}+\mathrm{ZPE})$ & $\Delta \mathbf{H}$ \\
\hline A & 0 & $0 \quad(164.90)^{(a)}$ & $0 \quad(172.10)^{(\mathrm{b})}$ & 0 & $0 \quad(154.90)^{(a)}$ & $0 \quad(162.39)^{(\mathrm{b})}$ \\
\hline $\mathrm{B}$ & 0.11 & $0.13 \quad(164.92)$ & $0.11(172.10)$ & 0.13 & $0.10(154.88)$ & $0.10 \quad(162.35)$ \\
\hline $\mathrm{C}$ & 0.19 & $0.31 \quad(165.02)$ & $0.23(172.14)$ & 0.22 & $0.19(154.87)$ & $0.17 \quad(162.34)$ \\
\hline $\mathrm{D}$ & 0.82 & $0.92 \quad(164.99)$ & $0.83(172.11)$ & 0.58 & $0.56(154.88)$ & $0.54 \quad(162.35)$ \\
\hline $\mathrm{E}$ & 0.81 & $1.06 \quad(165.14)$ & $0.90(172.19)$ & 0.80 & $0.78(154.88)$ & $0.73 \quad(162.32)$ \\
\hline $\mathrm{F}$ & 1.02 & $1.21 \quad(165.09)$ & $1.11(172.18)$ & 0.86 & $1.01(154.05)$ & $0.95 \quad(162.47)$ \\
\hline $\mathrm{G}$ & 1.10 & $1.21 \quad(165.09)$ & $1.11(172.22)$ & 1.03 & $1.10(154.97)$ & $1.03 \quad(162.38)$ \\
\hline $\mathrm{H}$ & 1.17 & $1.38 \quad(165.18)$ & $1.22(172.20)$ & 1.06 & $1.09(154.93)$ & $1.06 \quad(162.39)$ \\
\hline I & 1.74 & (165.09) & $1.27(172.23)$ & 1.38 & $1.52(154.05)$ & $1.44 \quad(162.45)$ \\
\hline
\end{tabular}

$\mathrm{E}+\mathrm{ZPE}$ is the internal energy taking account ZPE correction at $0 \mathrm{~K}$;

$\mathrm{H}$ is the enthalpy taking account the thermal contribution at $298 \mathrm{~K}$ and $1 \mathrm{~atm}$.

${ }^{\mathrm{a}, \mathrm{b}}$ Data in parentheses are respectively values of unscaled zero point energy and thermal contribution in hartree.

Table 2. Electronic energy (hartree) of the most stable conformer A and the relative energies $(\mathrm{kcal} / \mathrm{mol})$ of secondary conformers for different ab initio methods, with HF (a) and MP2 (b) optimization, involving 6-31 G** basis set.

\begin{tabular}{|l|l|l|l|l|}
\hline \multirow{2}{*}{ Conformer } & \multicolumn{4}{l|}{ Level of calculation } \\
\cline { 2 - 5 } & $\mathrm{HF} / / \mathrm{HF}^{\mathrm{a}}$ & $\mathrm{MP} / / \mathrm{HF}$ & $\mathrm{MP} 3 / / \mathrm{HF}$ & $\mathrm{MP}$ (DQ)//HF \\
\hline $\mathrm{A}$ & -313.45798 & -314.63630 & -314.72697 & -314.73199 \\
\hline $\mathrm{B}$ & 0.12 & 0.03 & 0.04 & 0.04 \\
\hline $\mathrm{C}$ & 0.18 & -0.09 & -0.01 & -0.02 \\
\hline $\mathrm{D}$ & 0.84 & 0.61 & 0.62 & 0.66 \\
\hline $\mathrm{E}$ & 0.82 & 0.19 & 0.34 & 0.33 \\
\hline & $\mathrm{HF} / / \mathrm{MP}^{\mathrm{b}}$ & $\mathrm{MP} / / \mathrm{MP} 2$ & $\mathrm{MP} 3 / / \mathrm{MP} 2$ & $\mathrm{MP} 4(\mathrm{DQ}) / / \mathrm{MP} 2$ \\
\hline $\mathrm{A}$ & -313.45729 & -314.63694 & -314.72728 & -314.73239 \\
\hline $\mathrm{B}$ & 0.12 & 0.01 & 0.03 & 0.03 \\
\hline $\mathrm{C}$ & 0.29 & -0.19 & -0.06 & -0.07 \\
\hline $\mathrm{D}$ & 0.81 & 0.63 & 0.62 & 0.67 \\
\hline $\mathrm{E}$ & 0.88 & 0.13 & 0.31 & 0.31 \\
\hline
\end{tabular}

Table 3. Electronic energy (hartree) of the most stable conformer A and the relative energies ( $\mathrm{kcal} / \mathrm{mol})$ of secondary conformers for DFT methods, involving 6-31G** basis set.

\begin{tabular}{|l|c|l|l|l|l|c|}
\hline \multirow{2}{*}{ Conformer } & \multicolumn{6}{|l|}{ Level of calculation } \\
\cline { 2 - 7 } & SVWN//SVWN & B3P86//B3P86 & B3PW91//B3PW91 & BLYP//BLYP & B3LYP//B3LYP & B3LYP//HF \\
\hline A & $-313.97364^{\text {(a) }}$ & -316.94203 & -315.62087 & -315.49803 & -315.73336 & -315.73215 \\
\hline B & 0.13 & 0.14 & 0.13 & 0.12 & 0.13 & 0.15 \\
\hline C & -0.25 & 0.16 & 0.20 & 0.24 & 0.21 & 0.23 \\
\hline D & 0.20 & 0.53 & 0.57 & 0.52 & 0.57 & 0.61 \\
\hline E & -0.03 & 0.65 & 0.77 & 0.89 & 0.79 & 0.80 \\
\hline
\end{tabular}



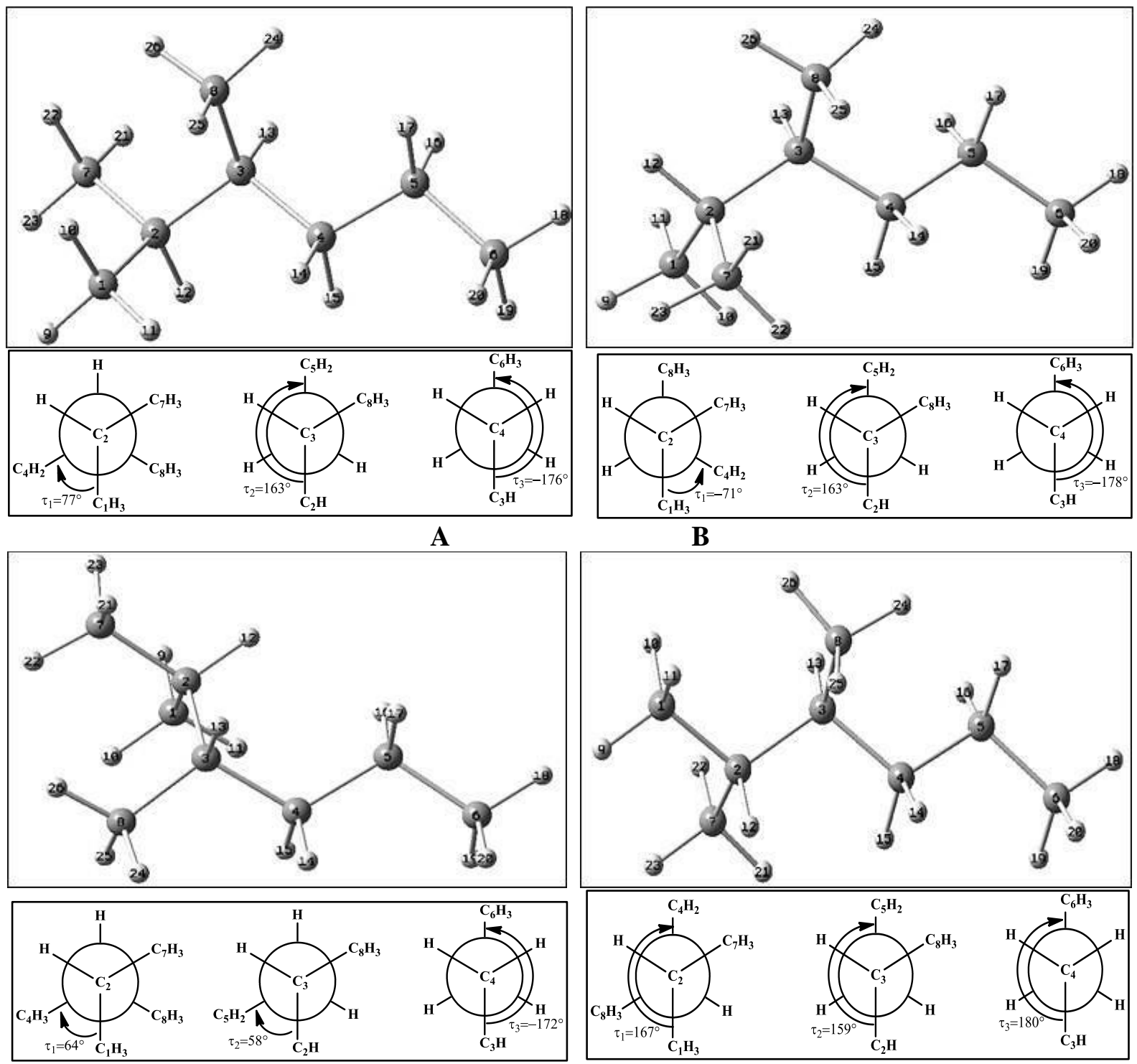

C

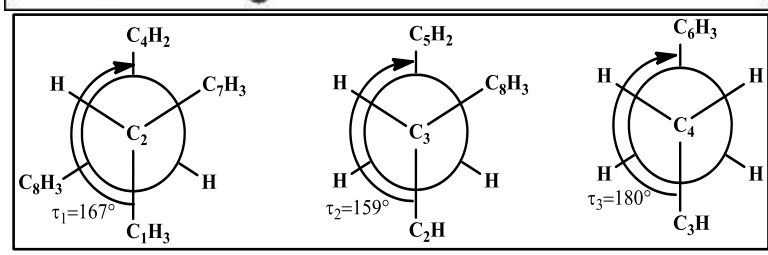

D

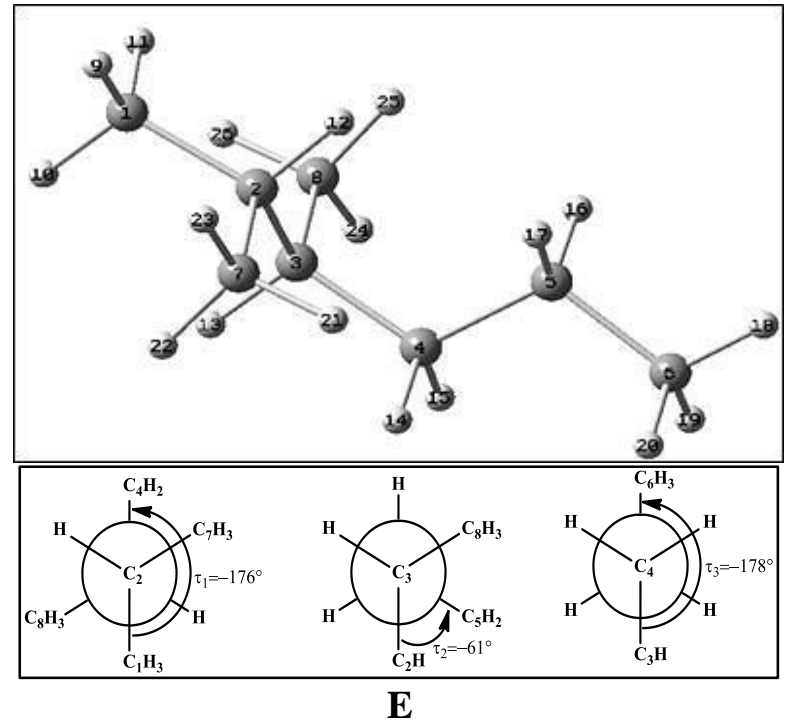

Figure 2. Stable conformations of 2,3-DMH 


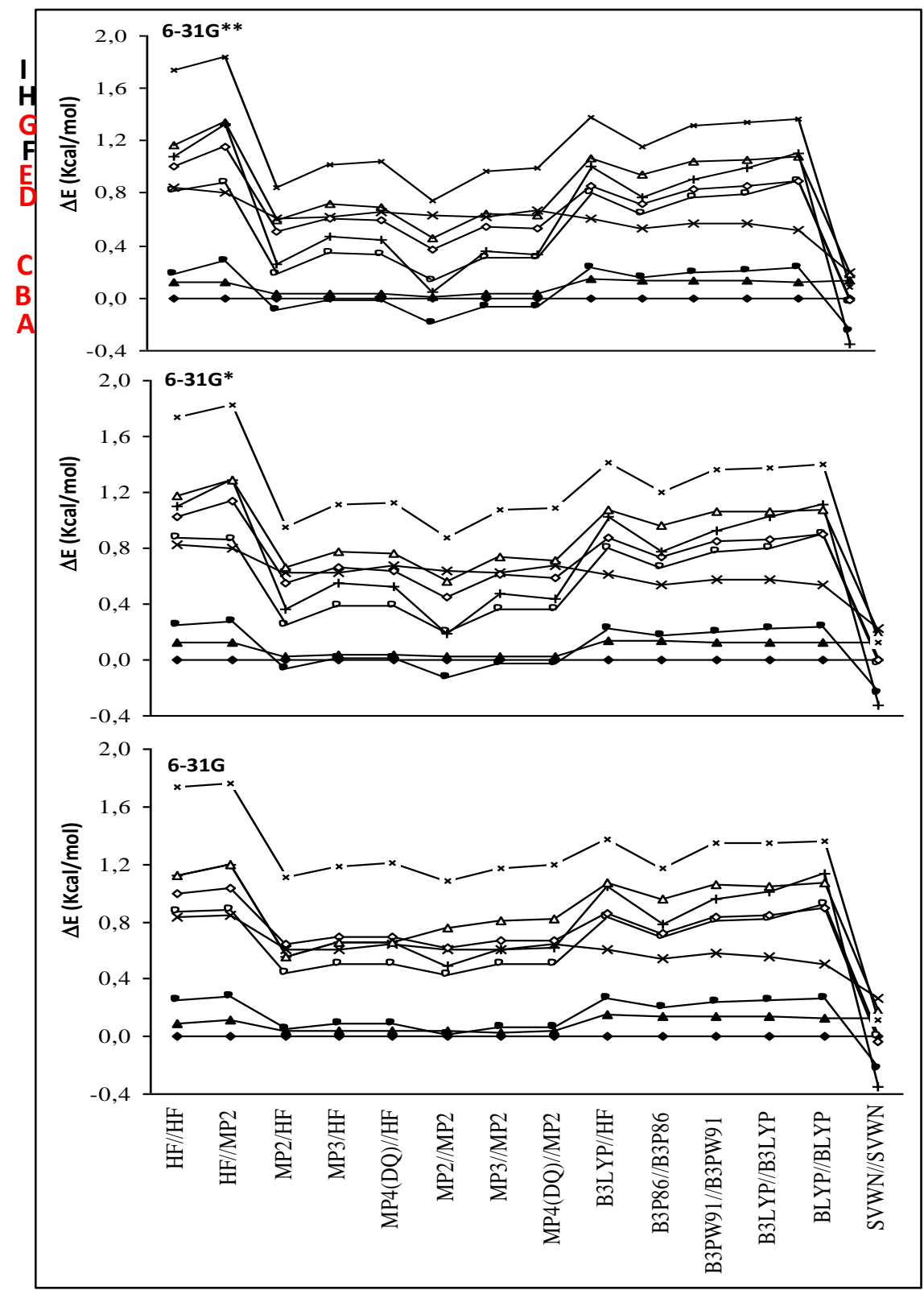

Figure 3. The correlation of the relative energies of 2,3- DMH conformers (A-I) obtained at various methods using 6-31G, 6-31G* and 6-31G** basis sets.

Table 5. Values $(\mathrm{kcal} / \mathrm{mol})$ of possible rotational barriers from the most stable conformer to the lowest energy secondary conformers and their correspondent inversion (in parentheses) barriers for 2,3-DMH.

\begin{tabular}{|l|l|l|l|}
\hline & $\mathbf{A} \rightarrow \mathbf{B}$ & $\mathbf{A} \rightarrow \mathbf{D}$ & $\mathbf{A} \rightarrow \mathbf{C}$ \\
\hline $\mathrm{HF} / 6-31 \mathrm{G}^{*}$ & $8.76(8.65)$ & $3.78(2.96)$ & $2.01(1.84)$ \\
\hline MP2/6-31G* & $8.64(8.63)$ & $4.05(3.44)$ & $2.15(2.28)$ \\
\hline
\end{tabular}

As can be seen, HF and DFT (other than LDA) give relative energies values higher than MPn, except for $\mathrm{D}$ conformer. In the same way, the stability ordering was modified by MPn calculations as E became more stable than $\mathrm{D}$ and $\mathrm{G}$ more stable than $\mathrm{F}$. The basis set extension consolidates this change, giving in addition, $\mathrm{C}$ more stable than $\mathrm{A}$ at 6-31G**. We noticed also that the optimization method has no effect on stability ordering, even it affects substantially MP2 relative energies of the secondary conformers like C, E, F and G. For instance, a decrease going until $0.2 \mathrm{kcal} / \mathrm{mol}$ is observed for $\mathrm{G}$ at $6-31 \mathrm{G}^{* *}$. Except for LDA where the relative energy values are very weak, the conformational stability ordering for DFT methods is similar to HF. Increase going until about 0.3 $\mathrm{kcal} / \mathrm{mol}$ is observed from B3P86 to BLYP for $\mathrm{G}$ conformer at $6-31 \mathrm{G}^{*}$ or at $6-31 \mathrm{G}^{* *}$. As an illustration, the three central torsional angles values for the optimized conformers A-E at MP2//MP2/6$31 \mathrm{G}^{* *}$ and B3LYP/B3LYP/6-31G** were collected in Table 4. 
In reality, the differences observed between $\mathrm{HF}$, post HF and DFT are due to the fact that HF method neglects static and dynamic correlation, DFT functionals associate a portion of exact HF exchange to an ab initio or empirical exchange and correlation while the explicitly correlated methods like MPn use anti bonding configurations. In addition, the DFT functionals investigated here for comparison, are doubtful in the evaluation of van der Waals interactions which play a prominent role during the conformers determination, especially when some conformers possess congested structures ${ }^{17,18}$.

On another aspect, the rotational barriers from the most stable conformer A to the lowest secondary conformers and their correspondent inversion barriers have been evaluated at both HF and MP2 methods using 6-31G* basis set, the optimization methods were respectively $\mathrm{HF}$ and MP2. In nbutane, the experimental value is $3.62 \mathrm{kcal} / \mathrm{mol}{ }^{19}$ with calculated values being $3.49^{20}$ and $3.31 \mathrm{kcal} / \mathrm{mol}^{21,22}$. In their work, Mirkin et al. found a good agreement between experimental values and MP2/6-31G* rotational barriers which were relatively larger than $\mathrm{HF} / 6-31 \mathrm{G}^{*}$ or $\mathrm{HF} / 6-31 \mathrm{G}$ ones 18,23 . Concerning 2,3-DMH, the onedimensional rotation from A leads to the following conformational changes:

Around $\mathrm{C} 2 \mathrm{C} 3$ bond:

A $\left(\tau_{1}=68, \tau_{2}=163, \tau_{3}=-176\right) \rightarrow$ B $\left(\tau_{1}=-70, \tau_{2}=163\right.$, $\left.\tau_{3}=-177\right)$

A $\left(\tau_{1}=68, \tau_{2}=163, \tau_{3}=-176\right) \rightarrow \mathrm{D}\left(\tau_{1}=167, \tau_{2}=159\right.$, $\left.\tau_{3}=180\right)$.

Around $\mathrm{C} 3 \mathrm{C} 4$ bond:

A $\left(\tau_{1}=68, \tau_{2}=163, \tau_{3}=-176\right) \rightarrow \mathrm{C}\left(\tau_{1}=64, \tau_{2}=58\right.$, $\left.\tau_{3}=172\right)$

For the latter for example, the torsion angle $\tau_{2}$ was kept at constant value from $45^{\circ}$ to $190^{\circ}$, in $5^{\circ}$ intervals, all the other bond lengths and angles were optimized. (Fig. 4).

According to the collected values in Tab. 5, MP2/6-31G* rotational barriers corresponding to A $\rightarrow \mathrm{C}$ and $\mathrm{A} \rightarrow \mathrm{D}$ transitions are larger than $\mathrm{HF} / 6$ $31 \mathrm{G}^{*}$ ones, the difference has reached for the latter about $0.3 \mathrm{kcal} / \mathrm{mol}$, this difference is more important for the inversion rotational barrier since it reaches $0.5 \mathrm{kcal} / \mathrm{mol}$. However, MP2/6-31G* rotational barrier for $\mathrm{A} \rightarrow \mathrm{B}$ transition decreases slightly while its inversion rotational barrier remains unchanged. Moreover, the high values of $\mathrm{A} \rightarrow \mathrm{B}$ rotational barrier and its inversion are due to the strong interaction of the $\mathrm{C} 1 \mathrm{C} 2 \mathrm{C} 7$ isopropyl group with the $\mathrm{C} 4 \mathrm{C} 3 \mathrm{C} 8$ group. Unfortunately, there are no experimental values for these barriers.

During the refinement of the ab initio normal modes frequencies, the 2,3- DMH scale factors of $\mathrm{HF} / 6-31 \mathrm{G}$ force constants were optimized in order to obtain the lowest rms deviation. Their values collected in Tab. 6 are almost the same as those obtained by Mirkin and Krimm for n-alkanes and some congested branched alkanes ${ }^{11,12}$, the most important difference does not exceed $10 \%$ and concerns CCC bending and CC torsion. Raman and IR frequencies in liquid phase as well as the calculated frequencies at $\mathrm{HF} / 6-31 \mathrm{G}$ level are listed in Tab. 7. The PED (contributions $\geq 10 \%$ ) for the most stable conformer $\mathrm{A}$ is given, except when its band doesn't exist, in which case the PED listed is for the existing lowest energy conformer. On the whole, the computed scaled frequencies are in good agreement with the experimental data leading rms deviation, not exceeding $6 \mathrm{~cm}^{-1}$ for frequencies below $1500 \mathrm{~cm}^{-1}$. As the molecule 2,3-DH contains $4 \mathrm{CH}_{3}, 2 \mathrm{CH}_{2}$ and $2 \mathrm{CH}$, its different vibration modes are subdivided in two groups. The first group (18 modes) contains 8 degenerate asymmetric stretching $\mathrm{CH}_{3}$ as (in plane and out of plane), 4 symmetric stretching $\mathrm{CH}_{3} \mathrm{ss}, 2$ asymmetric stretching $\mathrm{CH}_{2}$ as, 2 symmetric stretching $\mathrm{CH}_{2}$ ss and $2 \mathrm{CH}$ stretching (CHs). All these modes are pure, except $\mathrm{CH}_{2} \mathrm{ss}$ and $\mathrm{CHs}$, characterized by the predominant contribution of one to the other. The second group contains, as pure modes or in combination, 8 degenerate asymmetric deformations $\mathrm{CH}_{3} \mathrm{ab}$ (in plane and out of plane), 5 symmetric deformations $\mathrm{CH}_{3} \mathrm{sb}, 8$ degenerate rocking $\mathrm{CH}_{3} \mathrm{r}$ (in plane and out of plane), $2 \mathrm{CH}_{2}$ tw twisting, $2 \mathrm{CH}_{2}$ ro rocking, $4 \mathrm{CCH}$ defCH (in plane and out of plane) deformations as well as all related CC stretching and CCC deformations.

Based on the HF/6-31G scaled ab initio vibrational computations for the conformer A (Tab. 7), $\mathrm{CH}_{3} \mathrm{ab}$ was located as pure mode from 1386 to $1367 \mathrm{~cm}^{-1}$ and combined with $\mathrm{CH}_{2} \mathrm{~b}$ from 1466 to $1443 \mathrm{~cm}^{-1}, \mathrm{CH}_{3} \mathrm{sb}$ appears from 1386 to $1367 \mathrm{~cm}^{-1}$, essentially alone or, to a lesser extent, combined with $\mathrm{CH}_{2}$ wa while $\mathrm{HCC}$ deformation DefCH of the two tertiary carbons appears alone or combined with $\mathrm{CH}_{2}$ wa from 1354 to $1262 \mathrm{~cm}^{-1}$. As an illustration, DefCH contributes predominantly in the calculated modes 1350 (51\%) and 1342 (52\%), observed respectively at 1354 and $1337 \mathrm{~cm}^{-1}$ while it contributes with $\mathrm{CH}_{2}$ wa and/or $\mathrm{C} 2 \mathrm{C} 3$ stretching from 1320 to $1260 \mathrm{~cm}^{-1}$. Furthermore, the CC stretching acts within the range $1200-720 \mathrm{~cm}^{-1}$, essentially in combination with $\mathrm{CH}_{3} \mathrm{r}$ and $\mathrm{CH}_{2}$ ro, knowing that the latter mainly concerns the lower limits. The most important modes involving predominately $\mathrm{CC}$ contributions were calculated at 1055 (56\%), $1005(53 \%)$ and $756(56 \%)$ and observed at 1051,1009 and $776 \mathrm{~cm}^{-1}$ respectively. Concerning the CCC deformation, it appears in 550$280 \mathrm{~cm}^{-1}$ interval, except for the deformation mode of the central skeleton, to which contribute $\mathrm{C} 2 \mathrm{C} 3 \mathrm{C} 4$, $\mathrm{C} 3 \mathrm{C} 4 \mathrm{C} 5$ and $\mathrm{C} 4 \mathrm{C} 5 \mathrm{C} 6$ deformation coordinates, calculated at 148 like $\mathrm{CC}$ torsions, which are located globally in the range 260-30 $\mathrm{cm}^{-1}$ 


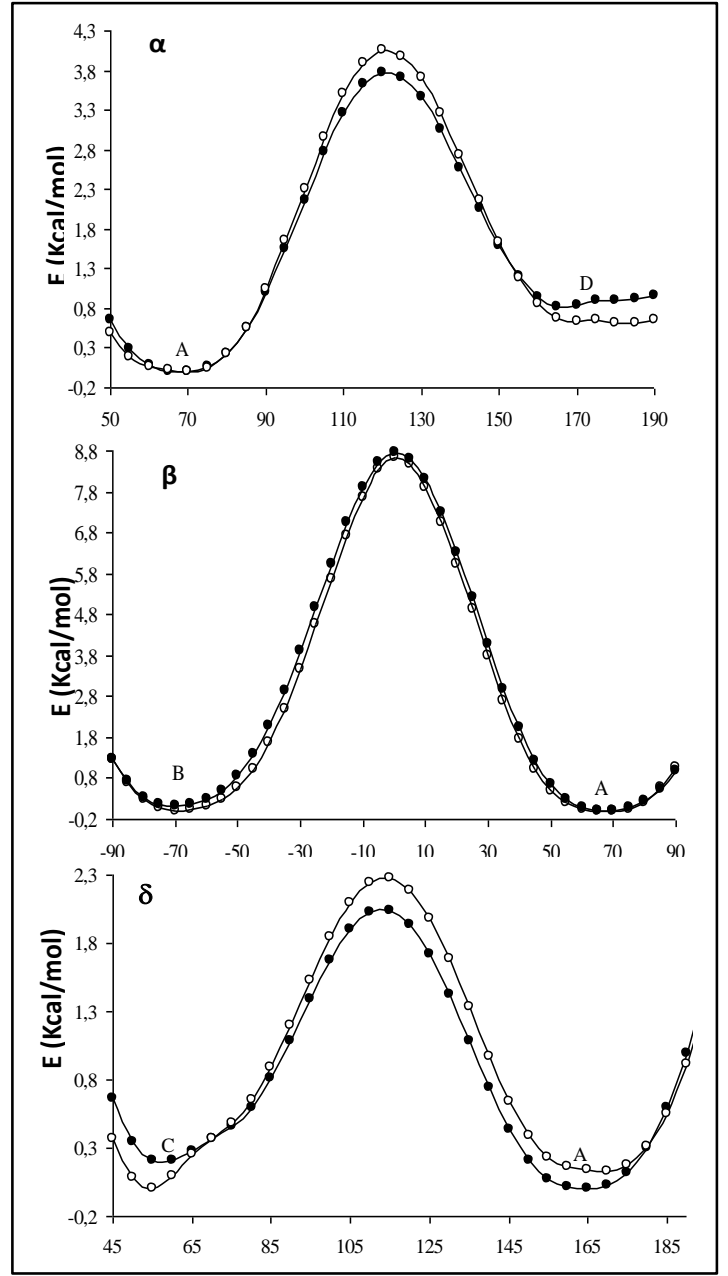

Figure $4 \mathrm{HF} / 6-31 \mathrm{G}^{*}(\bullet)$ and MP2/6-31G* (०) rotational barriers for:

$(\alpha): \mathbf{A}(\sim 70, \sim 160, \sim 180) \rightarrow \mathbf{D}(\sim 170, \sim 160, \sim 180)$

$(\beta): \mathbf{B}(\sim-70, \sim 160, \sim 180) \rightarrow \mathbf{A}(\sim 70, \sim 160, \sim 180)$

$(\delta): \mathbf{C}(\sim 60, \sim 60, \sim 170) \rightarrow \mathbf{A}(\sim 70, \sim 160, \sim 180)$

Table 6 Local symmetry coordinates scale factors for HF/ 6-31G constants and B3LYP/6-31G constants of conformers of 2,3-DMH.

\begin{tabular}{|l|l|l|}
\hline $\begin{array}{l}\text { Symmetry } \\
\text { coordinates }\end{array}$ & HF/ 6-31G & B3LYP/6-31G \\
\hline $\mathbf{C C s}$ & 0.871 & 0.976 \\
\hline $\mathbf{C H}_{3} \mathbf{s}$ & 0.830 & 0.909 \\
\hline $\mathbf{C H}_{2} \mathbf{s}$ & 0.815 & 0.900 \\
\hline $\mathbf{C H s}$ & 0.825 & 0.916 \\
\hline $\mathbf{C H}_{3} \mathbf{s b}$ & 0.760 & 0.891 \\
\hline $\mathbf{C H}_{3} \mathbf{a b}$ & 0.780 & 0.897 \\
\hline $\mathbf{C H}_{3} \mathbf{r}$ & 0.771 & 0.909 \\
\hline $\mathbf{C H}_{2} \mathbf{s b}$ & 0.768 & 0.893 \\
\hline $\mathbf{C H}_{2} \mathbf{r o}$ & 0.809 & 0.889 \\
\hline $\mathbf{C H}_{2} \mathbf{w a}$ & 0.775 & 0.894 \\
\hline $\mathbf{C H}_{2} \mathbf{t w}$ & 0.784 & 0.914 \\
\hline $\mathbf{C C C}_{\mathbf{C b}}$ & 0.825 & 0.936 \\
\hline $\mathbf{D e f} \mathbf{C H}$ & 0.763 & 0.925 \\
\hline $\mathbf{C C t}$ & 0.979 & 1.112 \\
\hline
\end{tabular}

In order to complete our conformational analysis, the normal modes of secondary conformers based on the same HF/6-31G scaled ab initio force field as the conformer A were determined. We have noticed that all the observed frequencies were reproduced by the vibrational mode calculation of $\mathrm{A}$, $\mathrm{B}, \mathrm{C}$ and D conformers, together. Indeed, almost all bands are common of these conformers, however certain bands were found specific to secondary conformers such as:

- the observed bands 1146 and $1124 \mathrm{~cm}^{-1}$ which correspond to modes due essentially to methyl rocking, the former was calculated at 1139 for C, 1153 for D while the latter was calculated at 1132 for A, 1129 for B. Thus, the band 1146 was reproduced by normal mode calculation for $\mathrm{C}$ and $\mathrm{D}$ while normal mode calculation of $\mathrm{A}$ and $\mathrm{B}$ reproduce $1124 \mathrm{~cm}^{-1}$ observed band. This situation was also found for $(868,861)$ observed pair of bands.

- the observed bands 789 and $776 \mathrm{~cm}^{-1}$ which is due essentially to CC stretching, the former was calculated at 784 for $\mathrm{D}$ while the latter was calculated at 756, 754 and 752 for A, B and C respectively. The same situation was found for $(1039,1031)$ and $(740,719)$ observed pairs of bands. - the observed bands 1146 and $1124 \mathrm{~cm}^{-1}$ which correspond to modes due essentially to methyl rocking, the former was calculated at 1139 for C and 1153 for $\mathrm{D}$, and the latter was calculated at 1132 for A and 1129 for B. This situation was also found for $(868,861)$ pair of bands.

- the observed bands 995, 981 and $971 \mathrm{~cm}^{-1}$, due essentially to methyl rocking, were calculated respectively at 991 for C, 980 and 986 for A and B, and at 968 for D.

For comparison, the B3LYP/6-31G vibrational analysis was also performed (Tab. 8), its rms (4.5 $\mathrm{cm}^{-1}$ ) was found comparable to HF/6-31G one (5.7 $\mathrm{cm}^{-1}$ ) for no $\mathrm{CH}$ stretching. Moreover, the frequencies predicted by HF/6-31G and B3LYP/6$31 \mathrm{G}$ rarely differ by more than $5 \mathrm{~cm}^{-1}$. Furthermore, both the two methods reproduce, almost the same potential energy distribution for all normal modes, essentially for the predominant contributions, except the mode observed at 995 assigned to $\mathrm{C}$ conformer, calculated by HF/6-31G at 991 as methyl rocking and by B3LYP/6-31G at 995 as CC stretching. In terms of conformational analysis, B3LYP/6-31G gives the same list of pair of bands sensitive to conformational stability. It should be noted, however, that the most important difference between the two methods was found in the values of the scale factors. The increase of scale factors of B3LYP/6$31 \mathrm{G}$ compared to HF/6-31G ones can sometimes reach up to $20 \%$ such as the scale factors of the $\mathrm{CH}_{2}$ wa and CCC deformation (Tab. 6). 
Table 7. Observed and calculated HF/6-31G frequencies $\left(\mathrm{cm}^{-1}\right)$ of 2,3 DMH.

\begin{tabular}{|c|c|c|c|c|c|}
\hline \multirow[t]{2}{*}{$v($ obs $)$} & \multicolumn{4}{|c|}{$v($ Calc) } & \multirow[t]{2}{*}{ Potential energy distribution (PED) ${ }^{a, b}$} \\
\hline & A & B & C & D & \\
\hline * & 1477 & 1474 & 1475 & 1486 & C8H3ab1(58)-C7H3ab2(18) \\
\hline 1466 & 1473 & 1472 & 1473 & 1475 & C1H3ab2(45)C8H3ab2(14)C7H3ab2(13)C7H3ab1(11) \\
\hline 1466 & 1472 & 1469 & 1472 & 1469 & C1H3ab1(37)-C7H3ab1(32)C8H3ab2(19) \\
\hline 1466 & 1468 & 1467 & 1468 & 1468 & C6H3ab1(53)-C5H2b(16) \\
\hline 1466 & 1465 & 1464 & 1465 & 1466 & C8H3ab2(24)-C8H3ab1(23)-C7H3ab2(14)-C6H3ab1(12)-C1H3ab1(10) \\
\hline 1466 & 1463 & 1463 & 1463 & 1464 & C6H3ab2(90) \\
\hline 1466 & 1459 & 1463 & 1459 & 1460 & C7H3ab2(35)-C1H3ab2(17)C8H3ab2(16)-C1H3ab1(15) \\
\hline 1458 & 1456 & 1455 & 1455 & 1455 & C5H2b(45)C6H3ab1(25)-C4H2b(21) \\
\hline 1458 & 1455 & 1455 & 1453 & 1454 & C7H3ab1(45)-C1H3ab2(19)C1H3ab1(14) \\
\hline 1443 & 1445 & 1445 & 1447 & 1445 & $\mathrm{C} 4 \mathrm{H} 2 \mathrm{~b}(61) \mathrm{C} 5 \mathrm{H} 2 \mathrm{~b}(24)$ \\
\hline 1386 & 1386 & 1385 & 1385 & 1385 & $\mathrm{C} 1 \mathrm{H} 3 \mathrm{sb}(41) \mathrm{C} 7 \mathrm{H} 3 \mathrm{sb}(35) \mathrm{C} 8 \mathrm{H} 3 \mathrm{sb}(17)$ \\
\hline 1377 & 1380 & 1379 & 1377 & 1378 & C6H3sb(37)-C8H3sb(28) \\
\hline 1377 & 1375 & 1376 & 1375 & 1376 & $\mathrm{C} 6 \mathrm{H} 3 \mathrm{sb}(47) \mathrm{C} 8 \mathrm{H} 3 \mathrm{sb}(34)$ \\
\hline 1367 & 1368 & 1368 & 1368 & 1369 & C7H3sb(38)-C1H3sb(37) \\
\hline 1367 & 1363 & 1365 & 1365 & & C4H2wa(23)-C5H2wa(21)-C7H3sb(12) \\
\hline 1354 & 1350 & 1350 & 1353 & 1354 & Déf'C3H(22)-Déf'C2H(19)-DéfC2H(10) \\
\hline 1337 & 1342 & 1342 & 1344 & 1340 & DéfC3H(25)DéfC2H(15)-Déf'C2H(12)-C5H2wa(11) \\
\hline$*$ & & & 1321 & 1327 & DéfC2H(20)-C5H2wa(19) C2C3s(11) \\
\hline 1308 & 1315 & 1316 & & 1309 & C5H2wa(29)DéfC2H(21)C4H2wa(18) \\
\hline 1308 & 1302 & 1308 & 1315 & 1302 & Déf'C2H(25)Déf'C3H(22) C2C3s(13) \\
\hline 1295 & 1292 & 1292 & 1287 & 1293 & $\mathrm{C} 5 \mathrm{H} 2 \mathrm{tw}(54)-\mathrm{C} 4 \mathrm{H} 2 \mathrm{tw}(25)$ \\
\hline 1262 & 1265 & 1266 & 1276 & 1263 & DéfC3H(32)C4H2wa(21)-DéfC2H(13) \\
\hline 1231 & 1241 & 1247 & 1240 & 1238 & $\mathrm{C} 4 \mathrm{H} 2 \mathrm{tw}(21) \mathrm{C} 5 \mathrm{H} 2 \mathrm{tw}(19)-\mathrm{C} 6 \mathrm{H} 3 \mathrm{r} 2(17)-\mathrm{C} 5 \mathrm{H} 2 \mathrm{ro}(11)$ \\
\hline * & 1197 & 1203 & 1200 & 1184 & $\mathrm{C} 2 \mathrm{C} 3 \mathrm{~s}(12)$ \\
\hline 1186 & 1179 & 1178 & 1179 & 1178 & C1H3r1(13)C7H3r2(11)-C8H3r1(11) \\
\hline 1160 & 1162 & 1164 & 1166 & 1158 & C7H3r1(12)-C3C4s(11)C7C2C3b(10) \\
\hline 1146 & & & 1139 & 1153 & $\mathrm{C} 1 \mathrm{H} 3 \mathrm{r} 2(19)-\mathrm{C} 8 \mathrm{H} 3 \mathrm{r} 2(18)-\mathrm{C} 3 \mathrm{C} 4 \mathrm{~s}(10)$ \\
\hline 1124 & 1132 & 1129 & & & $\mathrm{C} 1 \mathrm{H} 3 \mathrm{r} 2(19)-\mathrm{C} 8 \mathrm{H} 3 \mathrm{r} 2(18) \mathrm{C} 2 \mathrm{C} 7 \mathrm{~s}(11)$ \\
\hline 1074 & 1076 & 1072 & 1085 & 1080 & C6H3r1(24)-C4C5s(16) \\
\hline 1051 & 1055 & 1051 & 1055 & 1075 & C4C5s(21)-C5C6s(19)-C3C4s(16) \\
\hline 1039 & 1043 & & 1037 & 1040 & C5C6s(21)-C8H3r2(10) \\
\hline 1031 & & 1031 & & & C8H3r2(24)-C5C6s(11)-C1H3r2(11) \\
\hline 1009 & 1005 & 1013 & 998 & 1003 & C5C6s(24) C3C8s(18)-C3C4s(11) \\
\hline 995 & & & 991 & & C8H3r1(28) \\
\hline 981 & 980 & 986 & & & $\mathrm{C} 8 \mathrm{H} 3 \mathrm{r} 1(23)-\mathrm{C} 4 \mathrm{H} 2 \mathrm{tw}(14) \mathrm{C} 3 \mathrm{C} 8 \mathrm{~s}(11)$ \\
\hline 971 & & & & 968 & C8H3r1(33)C7H3r1(16) \\
\hline 942 & 951 & 947 & 954 & 949 & C7H3r1(37)-C1H3r2(17)-C1C2s(15) \\
\hline 937 & 933 & 942 & 941 & 948 & $\mathrm{C} 8 \mathrm{H} 3 \mathrm{r} 2(25) \mathrm{C} 1 \mathrm{H} 3 \mathrm{r} 2(17) \mathrm{C} 2 \mathrm{C} 3 \mathrm{~s}(13)-\mathrm{C} 3 \mathrm{C} 4 \mathrm{~s}(12)-\mathrm{C} 2 \mathrm{C} 7 \mathrm{~s}(10)$ \\
\hline 918 & 912 & 904 & 913 & 909 & C7H3r2(41)-C1H3r1(27)DéfC2H(11) \\
\hline 896 & 899 & 897 & 895 & 902 & $\mathrm{C} 6 \mathrm{H} 3 \mathrm{r} 1(20) \mathrm{C} 4 \mathrm{C} 5 \mathrm{~s}(15) \mathrm{C} 1 \mathrm{C} 2 \mathrm{~s}(10) \mathrm{C} 5 \mathrm{C} 6 \mathrm{~s}(10)$ \\
\hline 868 & & 868 & 872 & & C6H3r1(14)C4H2ro(11)-C8H3r1(11) \\
\hline 861 & 863 & & & 864 & C4H2ro(19)-C6H3r2(15)-C8H3r1(14) \\
\hline 850 & 845 & 850 & 856 & 845 & C6H3r2(16) C3C8s(15)-C4H2ro(14) \\
\hline 789 & & & & 784 & $\mathrm{C} 2 \mathrm{C} 3 \mathrm{~s}(23)$ \\
\hline 776 & 756 & 754 & 752 & & $\mathrm{C} 2 \mathrm{C} 3 \mathrm{~s}(29) \mathrm{C} 1 \mathrm{C} 2 \mathrm{~s}(16) \mathrm{C} 3 \mathrm{C} 8 \mathrm{~s}(11)$ \\
\hline 740 & 740 & 745 & & 738 & C5H2ro(50)-C4H2ro(22)-C6H3r2(13) \\
\hline 719 & & & 710 & & C2C3s(30)C4H2ro(15) \\
\hline 552 & 552 & 547 & 552 & & $\mathrm{C} 1 \mathrm{C} 2 \mathrm{C} 3 \mathrm{~b}(26)-\mathrm{C} 2 \mathrm{C} 3 \mathrm{C} 8 \mathrm{~b}(26) \mathrm{C} 7 \mathrm{C} 2 \mathrm{C} 3 \mathrm{~b}(12)$ \\
\hline
\end{tabular}




\begin{tabular}{|c|c|c|c|c|c|}
\hline$v($ obs $)$ & \multicolumn{4}{|c|}{$v($ Calc $)$} & \multirow[t]{2}{*}{ Potentiel energy distribution (PED) ${ }^{\text {a,b }}$} \\
\hline & $\mathbf{A}$ & $\mathbf{B}$ & $\mathbf{C}$ & D & \\
\hline 513 & & & 518 & 513 & $\mathrm{C} 2 \mathrm{C} 3 \mathrm{C} 4 \mathrm{~b}(28) \mathrm{C} 7 \mathrm{C} 2 \mathrm{C} 3 \mathrm{~b}(12)-\mathrm{C} 4 \mathrm{C} 5 \mathrm{C} 6 \mathrm{~b}(11)$ \\
\hline 504 & 501 & & & & $\mathrm{C} 8 \mathrm{C} 3 \mathrm{C} 4 \mathrm{~b}(21) \mathrm{C} 2 \mathrm{C} 3 \mathrm{C} 4 \mathrm{~b}(18) \mathrm{C} 7 \mathrm{C} 2 \mathrm{C} 3 \mathrm{~b}(16)-\mathrm{C} 4 \mathrm{C} 5 \mathrm{C} 6 \mathrm{~b}(15)$ \\
\hline 482 & & 477 & & & $\mathrm{C} 1 \mathrm{C} 2 \mathrm{C} 3 \mathrm{~b}(24) \mathrm{C} 2 \mathrm{C} 3 \mathrm{C} 8 \mathrm{~b}(21) \mathrm{C} 8 \mathrm{C} 3 \mathrm{C} 4 \mathrm{~b}(15)$ \\
\hline 460 & & & & 464 & $\mathrm{C} 2 \mathrm{C} 3 \mathrm{C} 8 \mathrm{~b}(30)-\mathrm{C} 1 \mathrm{C} 2 \mathrm{C} 3 \mathrm{~b}(16) \mathrm{C} 1 \mathrm{C} 2 \mathrm{C} 7 \mathrm{~b}(11)$ \\
\hline 444 & & 440 & & & $\mathrm{C} 8 \mathrm{C} 3 \mathrm{C} 4 \mathrm{~b}(21)-\mathrm{C} 3 \mathrm{C} 4 \mathrm{C} 5 \mathrm{~b}(13)-\mathrm{C} 1 \mathrm{C} 2 \mathrm{C} 7 \mathrm{~b}(13)$ \\
\hline 428 & 423 & & & 420 & $\mathrm{C} 1 \mathrm{C} 2 \mathrm{C} 7 \mathrm{~b}(48)$ \\
\hline 402 & & & 405 & & $\mathrm{C} 8 \mathrm{C} 3 \mathrm{C} 4 \mathrm{~b}(27)-\mathrm{C} 1 \mathrm{C} 2 \mathrm{C} 7 \mathrm{~b}(23)-\mathrm{C} 4 \mathrm{C} 5 \mathrm{C} 6 \mathrm{~b}(13)$ \\
\hline 402 & & & 400 & & $\mathrm{C} 1 \mathrm{C} 2 \mathrm{C} 7 \mathrm{~b}(40) \mathrm{C} 3 \mathrm{C} 4 \mathrm{C} 5 \mathrm{~b}(15) \mathrm{C} 8 \mathrm{C} 3 \mathrm{C} 4 \mathrm{~b}(13)$ \\
\hline$*$ & & & & 384 & $\mathrm{C} 1 \mathrm{C} 2 \mathrm{t}(18) \mathrm{C} 3 \mathrm{C} 8 \mathrm{t}(17)-\mathrm{C} 2 \mathrm{C} 3 \mathrm{C} 8 \mathrm{~b}(13) \mathrm{C} 8 \mathrm{C} 3 \mathrm{C} 4 \mathrm{~b}(11)$ \\
\hline 365 & & 362 & & 374 & $\mathrm{C} 1 \mathrm{C} 2 \mathrm{C} 7 \mathrm{~b}(21) \mathrm{C} 7 \mathrm{C} 2 \mathrm{C} 3 \mathrm{~b}(17)-\mathrm{C} 8 \mathrm{C} 3 \mathrm{C} 4 \mathrm{~b}(16)$ \\
\hline 335 & 344 & & & 339 & C8C3C4b(44)C4C5C6b(18)C1C2C7b(13) \\
\hline 313 & 305 & 324 & 318 & 307 & $\mathrm{C} 7 \mathrm{C} 2 \mathrm{C} 3 \mathrm{~b}(30) \mathrm{C} 4 \mathrm{C} 5 \mathrm{C} 6 \mathrm{~b}(21)-\mathrm{C} 1 \mathrm{C} 2 \mathrm{C} 7 \mathrm{~b}(12) \mathrm{C} 3 \mathrm{C} 4 \mathrm{~s}(11)$ \\
\hline$*$ & 291 & 284 & 292 & & $\mathrm{C} 2 \mathrm{C} 3 \mathrm{C} 8 \mathrm{~b}(29) \mathrm{C} 7 \mathrm{C} 2 \mathrm{C} 3 \mathrm{~b}(21)-\mathrm{C} 3 \mathrm{C} 4 \mathrm{C} 5 \mathrm{~b}(18)$ \\
\hline$*$ & 284 & 267 & 275 & & $\mathrm{C} 1 \mathrm{C} 2 \mathrm{C} 3 \mathrm{~b}(46) \mathrm{C} 2 \mathrm{C} 3 \mathrm{C} 8 \mathrm{~b}(19)$ \\
\hline$*$ & 259 & 250 & 262 & 272 & $\mathrm{C} 1 \mathrm{C} 2 \mathrm{t}(58) \mathrm{C} 3 \mathrm{C} 8 \mathrm{t}(27)$ \\
\hline$*$ & 245 & 242 & 250 & 263 & C5C6t(61)C2C7t(17) \\
\hline$*$ & 237 & 231 & 241 & 253 & C2C7t(59)-C5C6t(23) \\
\hline$*$ & 207 & 217 & 211 & 227 & $\mathrm{C} 3 \mathrm{C} 8 \mathrm{t}(49)-\mathrm{C} 1 \mathrm{C} 2 \mathrm{t}(31)-\mathrm{C} 2 \mathrm{C} 7 \mathrm{t}(12)$ \\
\hline$*$ & 148 & 156 & 166 & 173 & $\mathrm{C} 3 \mathrm{C} 4 \mathrm{C} 5 \mathrm{~b}(31)-\mathrm{C} 2 \mathrm{C} 3 \mathrm{C} 4 \mathrm{~b}(29)-\mathrm{C} 4 \mathrm{C} 5 \mathrm{C} 6 \mathrm{~b}(17)$ \\
\hline$*$ & 94 & 94 & 117 & 96 & C4C5t(49)-C3C8t(14) \\
\hline$*$ & 74 & 74 & 80 & 65 & $\mathrm{C} 3 \mathrm{C} 4 \mathrm{t}(36)-\mathrm{C} 2 \mathrm{C} 3 \mathrm{t}(26)$ \\
\hline$*$ & 36 & 48 & 42 & 54 & C3C4t(34)C2C3t(31)C3C8t(15)C4C5t(10) \\
\hline
\end{tabular}

a Potential energy distribution (contribution $\geq 10$ ) for A conformer, except when no A band is given, in which case the PED is for the existing secondary conformer.

b CH3sb, totally symmetric bending of $\mathrm{CH}_{3} ; \mathrm{CH}_{3} \mathrm{ab} 1\left(\mathrm{CH}_{3} \mathrm{ab} 2\right)$, in plane (out of plane) degenerate bending of $\mathrm{CH}_{3} ; \mathrm{CH}_{3} \mathrm{rl}\left(\mathrm{CH}_{3} \mathrm{r} 2\right.$ ), in plane (out of plane) degenerate rocking of $\mathrm{CH}_{3} ; \mathrm{CH}_{2} \mathrm{~b}$, scissoring of $\mathrm{CH}_{2} ; \mathrm{CH}_{2} \mathrm{tw}$, twisting of $\mathrm{CH}_{2} ; \mathrm{CH}_{2}$ ro, rocking of $\mathrm{CH}_{2} ; \mathrm{CH}_{2}$ wa, wagging of $\mathrm{CH}_{2}$; Def $\mathrm{CH}\left(\right.$ Def ${ }^{\prime} \mathrm{CH}$ ), in plane (out of plane) deformation $\mathrm{CCH}$; $\mathrm{CCCb}, \mathrm{CCC}$ deformation; $\mathrm{CCs}$, $\mathrm{CC}$ stretching; $\mathrm{CCt}$, $\mathrm{CC}$ torsion.

\section{Conclusion}

In light of this work, we can conclude that ZPE, thermal contribution to internal and enthalpic energies have an effect barely perceptible on the HF/6-31G* conformational stability ordering and no effect on B3LYP/6-31G* one. Further, the stability ordering was modified by MPn calculations and the basis set extension, while the optimization method has no effect. MP2/6-31G* rotational barriers corresponding to $\mathrm{A} \rightarrow \mathrm{C}$ and $\mathrm{A} \rightarrow \mathrm{D}$ transitions are larger than $\mathrm{HF} / 6-31 \mathrm{G}^{*}$ ones. However, MP2/6-31G* rotational barrier for $\mathrm{A} \rightarrow \mathrm{B}$ transition decreases slightly. Concerning the vibrational analysis, HF/6-
$31 \mathrm{G}$ as well as B3LYP/6-31G led to the same sensitive pair of bands to conformational stability. Even the difference between the optimized HF/6$31 \mathrm{G}$ and B3LYP/6-31G scale factors can sometimes reach up to $20 \%$, their obtained rms deviation were found comparable.

Regarding its simplicity and its ab initio character, the scaled $a b$ initio force field of branched hexanes seems to be complete and useful as a basis for the development of spectroscopically accurate molecular mechanics energy function for the derived polymers.

Table 8. Observed and calculated B3LYP/6-31G frequencies $\left(\mathrm{cm}^{-1}\right)$ of 2,3 DMH.

\begin{tabular}{|c|c|c|c|c|l|}
\hline \multirow{2}{*}{$v($ obs $)$} & \multicolumn{4}{|c|}{$v($ Calc) } & Potential energy distribution (PED) \\
& a,b \\
\hline 1466 & 1476 & 1474 & 1472 & 1483 & C8H3ab1(52)-C7H3ab2(11) \\
\hline 1466 & 1472 & 1472 & 1472 & 1475 & C1H3ab2(26)C7H3ab2(20)C7H3ab1(14) \\
\hline 1466 & 1471 & 1470 & 1470 & 1468 & C1H3ab1(42)C8H3ab2(23)-C7H3ab1(22) \\
\hline 1466 & 1470 & 1466 & 1468 & 1466 & C6H3ab1(27)-C5H2b(23)C1H3ab2(16) \\
\hline 1466 & 1463 & 1463 & 1463 & 1461 & C8H3ab2(32)-C8H3ab1(18)-C1H3ab1(17)-C7H3ab2(11) \\
\hline 1466 & 1461 & 1462 & 1462 & 1461 & C6H3ab2(88) \\
\hline
\end{tabular}




\begin{tabular}{|c|c|c|c|c|c|}
\hline 1466 & 1457 & 1461 & 1456 & 1457 & $\mathrm{C} 6 \mathrm{H} 3 \mathrm{ab} 1(51) \mathrm{C} 5 \mathrm{H} 2 \mathrm{~b}(28)-\mathrm{C} 4 \mathrm{H} 2 \mathrm{~b}(14)$ \\
\hline 1458 & 1454 & 1455 & 1454 & 1454 & C7H3ab2(31)-C1H3ab2(20)C8H3ab1(12)C4H2b(10) \\
\hline 1458 & 1451 & 1453 & 1450 & 1451 & C7H3ab1(40)C1H3ab1(19)-C7H3ab2(17) \\
\hline 1443 & 1446 & 1443 & 1444 & 1446 & $\mathrm{C} 4 \mathrm{H} 2 \mathrm{~b}(44) \mathrm{C} 5 \mathrm{H} 2 \mathrm{~b}(17) \mathrm{C} 1 \mathrm{H} 3 \mathrm{ab} 2(14)-\mathrm{C} 8 \mathrm{H} 3 \mathrm{ab} 2(13)$ \\
\hline 1386 & 1387 & 1386 & 1396 & 1385 & $\mathrm{C} 1 \mathrm{H} 3 \mathrm{sb}(35) \mathrm{C} 8 \mathrm{H} 3 \mathrm{sb}(29) \mathrm{C} 7 \mathrm{H} 3 \mathrm{sb}(28)$ \\
\hline 1377 & 1380 & 1381 & 1381 & 1380 & $\mathrm{C} 6 \mathrm{H} 3 \mathrm{sb}(56)$ \\
\hline 1377 & 1375 & 1377 & 1373 & 1376 & $\mathrm{C} 8 \mathrm{H} 3 \mathrm{sb}(45) \mathrm{C} 6 \mathrm{H} 3 \mathrm{sb}(25)-\mathrm{C} 1 \mathrm{H} 3 \mathrm{sb}(11)$ \\
\hline 1367 & 1367 & 1367 & 1369 & 1367 & $\mathrm{C} 1 \mathrm{H} 3 \mathrm{sb}(36)-\mathrm{C} 7 \mathrm{H} 3 \mathrm{sb}(27)$ \\
\hline 1367 & 1363 & 1364 & 1363 & & $\mathrm{C} 7 \mathrm{H} 3 \mathrm{sb}(25)$ \\
\hline 1354 & 1351 & 1354 & 1355 & 1352 & C5H2wa(31)-DéfC2H(13)-C4H2w(13) \\
\hline 1337 & 1342 & 1337 & 1342 & 1335 & Déf'C2H(19)-Déf'C3H(19)-DéfC3H(15) \\
\hline$*$ & & & 1328 & 1326 & Déf'C3H(23)Déf'C2H(14)DéfC2H(12) \\
\hline 1308 & 1317 & 1310 & & 1312 & C5H2wa(27)C4H2w(20)DéfC2H(17) \\
\hline 1308 & 1298 & 1307 & 1309 & 1303 & Déf'C2H(26)Déf'C3H(22)C2C3s(11) \\
\hline 1295 & 1291 & 1295 & 1293 & 1293 & $\mathrm{C} 5 \mathrm{H} 2 \mathrm{tw}(55)-\mathrm{C} 4 \mathrm{H} 2 \mathrm{tw}(30)$ \\
\hline 1262 & 1269 & 1263 & 1259 & 1267 & DéfC3H(34)C4H2w(21)-DéfC2H(15) \\
\hline 1231 & 1239 & 1245 & 1241 & 1238 & $\mathrm{C} 4 \mathrm{H} 2 \mathrm{tw}(25) \mathrm{C} 5 \mathrm{H} 2 \mathrm{tw}(20)-\mathrm{C} 6 \mathrm{H} 3 \mathrm{r} 2(16)-\mathrm{C} 5 \mathrm{H} 2 \mathrm{ro}(10)$ \\
\hline$*$ & 1193 & 1208 & 1196 & 1184 & $\mathrm{C} 2 \mathrm{C} 3 \mathrm{~s}(14)$ \\
\hline 1186 & 1178 & 1177 & 1180 & 1174 & C8H3r1(12)-C1H3r1(12)C4H2ro(11) \\
\hline 1160 & 1162 & 1163 & 1166 & 1158 & $\mathrm{C} 7 \mathrm{H} 3 \mathrm{r} 1(12)-\mathrm{C} 3 \mathrm{C} 4 \mathrm{~s}(11) \mathrm{C} 7 \mathrm{C} 2 \mathrm{C} 3 \mathrm{~b}(11)$ \\
\hline 1146 & & & 1138 & 1154 & $\mathrm{C} 1 \mathrm{H} 3 \mathrm{r} 2(18)-\mathrm{C} 8 \mathrm{H} 3 \mathrm{r} 2(18)-\mathrm{C} 3 \mathrm{C} 4 \mathrm{~s}(11)$ \\
\hline 1124 & 1131 & 1128 & & & $\mathrm{C} 8 \mathrm{H} 3 \mathrm{r} 2(19)-\mathrm{C} 1 \mathrm{H} 3 \mathrm{r} 2(18)$ \\
\hline 1074 & 1076 & 1074 & 1079 & 1078 & C6H3r1(24)-C4C5s(15) \\
\hline 1051 & 1053 & 1053 & 1059 & 1074 & C4C5s(21)-C5C6s(18)-C3C4s(16) \\
\hline 1039 & 1044 & & 1037 & 1038 & C5C6s(25) \\
\hline 1031 & & 1030 & & & C8H3r2(18)-C5C6s(14) \\
\hline 1009 & 1004 & 1011 & 999 & 1002 & C5C6s(24)C3C8s(14)-C3C4s(12)-C8H3r1(10) \\
\hline 995 & & & 995 & & $\mathrm{C} 3 \mathrm{C} 8 \mathrm{~s}(36)$ \\
\hline 981 & 980 & 986 & & & C8H3r1(19)C3C8s(16)-C4H2tw(14) \\
\hline 971 & & & & 971 & C8H3r1(35)C7H3r1(14) \\
\hline 942 & 952 & 943 & 955 & 951 & C7H3r1(37)-C1H3r2(17)-C1C2s(14) \\
\hline 937 & 928 & 936 & 935 & 941 & $\mathrm{C} 8 \mathrm{H} 3 \mathrm{r} 2(21) \mathrm{C} 1 \mathrm{H} 3 \mathrm{r} 2(14) \mathrm{C} 2 \mathrm{C} 3 \mathrm{~s}(13)-\mathrm{C} 3 \mathrm{C} 4 \mathrm{~s}(12)$ \\
\hline 918 & 915 & 901 & 914 & 915 & C7H3r2(39)-C1H3r1(29)DéfC2H(11) \\
\hline 896 & 900 & 896 & 892 & 903 & C6H3r1(18)C1C2s(15)C4C5s(14) \\
\hline 868 & & 872 & 874 & & C4H2ro(21)-C6H3r2(17)C6H3r1(10) \\
\hline 861 & 864 & & & 865 & $\mathrm{C} 4 \mathrm{H} 2 \mathrm{ro}(17)-\mathrm{C} 8 \mathrm{H} 3 \mathrm{r} 1(14)-\mathrm{C} 6 \mathrm{H} 3 \mathrm{r} 2(13)$ \\
\hline 850 & 845 & 857 & 859 & 847 & C6H3r2(17)-C4H2ro(16)C3C8s(15) \\
\hline 789 & & & & 782 & $\mathrm{C} 2 \mathrm{C} 3 \mathrm{~s}(24)$ \\
\hline 776 & 756 & 775 & 758 & & $\mathrm{C} 2 \mathrm{C} 3 \mathrm{~s}(31) \mathrm{C} 1 \mathrm{C} 2 \mathrm{~s}(16) \mathrm{C} 3 \mathrm{C} 8 \mathrm{~s}(10)$ \\
\hline 740 & 742 & 755 & & 743 & C5H2ro(50)-C4H2ro(22)-C6H3r2(13) \\
\hline 719 & & & 711 & & $\mathrm{C} 2 \mathrm{C} 3 \mathrm{~s}(35) \mathrm{C} 4 \mathrm{H} 2 \mathrm{ro}(14)$ \\
\hline 552 & 556 & 549 & 555 & & $\mathrm{C} 1 \mathrm{C} 2 \mathrm{C} 3 \mathrm{~b}(26)-\mathrm{C} 2 \mathrm{C} 3 \mathrm{C} 8 \mathrm{~b}(26) \mathrm{C} 7 \mathrm{C} 2 \mathrm{C} 3 \mathrm{~b}(12)$ \\
\hline 513 & & & 520 & 516 & $\mathrm{C} 2 \mathrm{C} 3 \mathrm{C} 4 \mathrm{~b}(27) \mathrm{C} 7 \mathrm{C} 2 \mathrm{C} 3 \mathrm{~b}(11)-\mathrm{C} 4 \mathrm{C} 5 \mathrm{C} 6 \mathrm{~b}(11)$ \\
\hline 504 & 503 & & & & $\mathrm{C} 8 \mathrm{C} 3 \mathrm{C} 4 \mathrm{~b}(20) \mathrm{C} 2 \mathrm{C} 3 \mathrm{C} 4 \mathrm{~b}(18) \mathrm{C} 7 \mathrm{C} 2 \mathrm{C} 3 \mathrm{~b}(16)-\mathrm{C} 4 \mathrm{C} 5 \mathrm{C} 6 \mathrm{~b}(15)$ \\
\hline 482 & & 479 & & & $\mathrm{C} 1 \mathrm{C} 2 \mathrm{C} 3 \mathrm{~b}(25) \mathrm{C} 2 \mathrm{C} 3 \mathrm{C} 8 \mathrm{~b}(21) \mathrm{C} 8 \mathrm{C} 3 \mathrm{C} 4 \mathrm{~b}(16)$ \\
\hline 460 & & & & 463 & $\mathrm{C} 2 \mathrm{C} 3 \mathrm{C} 8 \mathrm{~b}(30) \mathrm{C} 1 \mathrm{C} 2 \mathrm{C} 7 \mathrm{~b}(15)-\mathrm{C} 1 \mathrm{C} 2 \mathrm{C} 3 \mathrm{~b}(13)$ \\
\hline 444 & & 440 & & & $\mathrm{C} 8 \mathrm{C} 3 \mathrm{C} 4 \mathrm{~b}(21)-\mathrm{C} 3 \mathrm{C} 4 \mathrm{C} 5 \mathrm{~b}(13)-\mathrm{C} 1 \mathrm{C} 2 \mathrm{C} 7 \mathrm{~b}(13)$ \\
\hline 428 & 425 & & & 423 & $\mathrm{C} 1 \mathrm{C} 2 \mathrm{C} 7 \mathrm{~b}(48)$ \\
\hline 402 & & & 404 & & $\mathrm{C} 8 \mathrm{C} 3 \mathrm{C} 4 \mathrm{~b}(39) \mathrm{C} 3 \mathrm{C} 4 \mathrm{C} 5 \mathrm{~b}(11)$ \\
\hline 402 & & & 401 & & $\mathrm{C} 1 \mathrm{C} 2 \mathrm{C} 7 \mathrm{~b}(60)$ \\
\hline
\end{tabular}




\begin{tabular}{|c|c|c|c|c|c|}
\hline$*$ & & & & 384 & $\mathrm{C} 2 \mathrm{C} 3 \mathrm{C} 8 \mathrm{~b}(18)-\mathrm{C} 3 \mathrm{C} 8 \mathrm{t}(12) \mathrm{C} 2 \mathrm{C} 3 \mathrm{C} 4 \mathrm{~b}(11)-\mathrm{C} 1 \mathrm{C} 2 \mathrm{C} 7 \mathrm{~b}(11)$ \\
\hline 365 & & 364 & & 374 & C8C3C4b(44)C4C5C6b(18)C1C2C7b(14) \\
\hline 335 & 347 & & & 332 & C8C3C4b(44)C4C5C6b(18)C1C2C7b(14) \\
\hline 313 & 306 & 326 & 318 & 309 & $\mathrm{C} 7 \mathrm{C} 2 \mathrm{C} 3 \mathrm{~b}(30) \mathrm{C} 4 \mathrm{C} 5 \mathrm{C} 6 \mathrm{~b}(21)-\mathrm{C} 1 \mathrm{C} 2 \mathrm{C} 7 \mathrm{~b}(13) \mathrm{C} 3 \mathrm{C} 4 \mathrm{~s}(11)$ \\
\hline$*$ & 293 & 286 & 290 & & $\mathrm{C} 2 \mathrm{C} 3 \mathrm{C} 8 \mathrm{~b}(26) \mathrm{C} 7 \mathrm{C} 2 \mathrm{C} 3 \mathrm{~b}(21)-\mathrm{C} 3 \mathrm{C} 4 \mathrm{C} 5 \mathrm{~b}(19)$ \\
\hline$*$ & 288 & 272 & 271 & & $\mathrm{C} 1 \mathrm{C} 2 \mathrm{C} 3 \mathrm{~b}(46) \mathrm{C} 2 \mathrm{C} 3 \mathrm{C} 8 \mathrm{~b}(22)$ \\
\hline$*$ & 257 & 254 & 257 & 260 & $\mathrm{C} 1 \mathrm{C} 2 \mathrm{t}(49) \mathrm{C} 3 \mathrm{C} 8 \mathrm{t}(34)$ \\
\hline$*$ & 245 & 249 & 242 & 258 & C5C6t(70)-C1C2t(11) \\
\hline$*$ & 235 & 240 & 230 & 228 & C2C7t(61)-C5C6t(15) \\
\hline$*$ & 213 & 231 & 212 & 215 & $\mathrm{C} 3 \mathrm{C} 8 \mathrm{t}(43)-\mathrm{C} 1 \mathrm{C} 2 \mathrm{t}(32)-\mathrm{C} 2 \mathrm{C} 7 \mathrm{t}(19)$ \\
\hline$*$ & 149 & 157 & 168 & 162 & C3C4C5b(31)-C2C3C4b(28)-C4C5C6b(18) \\
\hline * & 94 & 99 & 111 & 97 & $\mathrm{C} 4 \mathrm{C} 5 \mathrm{t}(37)-\mathrm{C} 3 \mathrm{C} 4 \mathrm{t}(19)-\mathrm{C} 3 \mathrm{C} 8 \mathrm{t}(14)-\mathrm{C} 2 \mathrm{C} 3 \mathrm{t}(12)$ \\
\hline$*$ & 78 & 76 & 74 & 66 & $\mathrm{C} 3 \mathrm{C} 4 \mathrm{t}(37)-\mathrm{C} 2 \mathrm{C} 3 \mathrm{t}(27) \mathrm{C} 4 \mathrm{C} 5 \mathrm{t}(10)$ \\
\hline$*$ & 44 & 57 & 37 & 37 & $\mathrm{C} 3 \mathrm{C} 4 \mathrm{t}(32) \mathrm{C} 2 \mathrm{C} 3 \mathrm{t}(32) \mathrm{C} 4 \mathrm{C} 5 \mathrm{t}(16) \mathrm{C} 3 \mathrm{C} 8 \mathrm{t}(11)$ \\
\hline
\end{tabular}

\section{References}

1- M. Macchione, J.C. Jansen, G. De Luca, E. Tocci, M. Longeri, E. Drioli, Polymer, 2007, 48, 2619.

2- Denis Bertina, Sandra Grimaldib, Marie Leblanca, Sylvain R.A. Marquea, Didier Siria, Paul Tordoa, J. Mol. Struct., 2007, 811, 255-266.

3- Arthur J. LaPlante, Howard D. Stidham, Gamil A. Guirgis, Horace W. Dukes, J. Mol. Struct., 2012, 1023, 170-175.

4- A. Suvitha, S. Periandy, M. Govindarajan, P. Gayathri Spectrochimica Acta Part A: Molecular and Biomolecular Spectroscopy, 2015, 138, 900-912.

5- E. B. Wilson, J. C. Decius, P. C. Cross, Molecular Vibrations (N. Y. : McGraw-Hill, 1955).

6- S. Califano, Vibrational States (N. Y. : J. Willey and Sons, 1976).

7- I.A. Shaaban, A.E. Hassan, A.M. Abuelela, W.M. Zoghaieb, T.A. Mohamed, Journal of Molecular Structure, 2016, 1003, 70-81.

8- K.Govindarasu, E. Kavitha, Journal of Molecular Structure, 2015, 1088, 70-84.

9- S. Subashchandrabose, V. Thanikachalam, G. Manikandan, H. Saleem, Y. Erdogdu, Spectrochimica Acta Part A, 2016, 157, 96-103.

10- G. E. Segal (Ed.): Semiempirical Methods of Electronic Structure Calculation, Part B: Applications, Vol. 8. Plenum Press, London, New York, 1977.

11- N. G. Mirkin, S. Krimm, J. Phys. Chem., 1993, 97, 13887.

12- N. G. Mirkin, S. Krimm, J. Mol. Struct., 2000, 67, 550-551.

13- Gaussian 03, Revision C.02, M. J. Frisch, G. W. Trucks, H. B. Schlegel, G. E. Scuseria, M. A. Robb, J. R. Cheeseman, J. A. Montgomery, Jr., T. Vreven, K. N. Kudin, J. C. Burant, J. M.
Millam, S. S. Iyengar, J. Tomasi, V. Barone, B. Mennucci, M. Cossi, G. Scalmani, N. Rega, G. A. Petersson, H. Nakatsuji, M. Hada, M. Ehara, K. Toyota, R. Fukuda, J. Hasegawa, M. Ishida, T. Nakajima, Y. Honda, O. Kitao, H. Nakai, M. Klene, X. Li, J. E. Knox, H. P. Hratchian, J. B. Cross, V. Bakken, C. Adamo, J. Jaramillo, R. Gomperts, R. E. Stratmann, O. Yazyev, A. J. Austin, R. Cammi, C. Pomelli, J. W. Ochterski, P. Y. Ayala, K. Morokuma, G. A. Voth, P. Salvador, J. J. Dannenberg, V. G. Zakrzewski, S. Dapprich, A. D. Daniels, M. C. Strain, O. Farkas, D. K. Malick, A. D. Rabuck, K. Raghavachari, J. B. Foresman, J. V. Ortiz, Q. Cui, A. G. Baboul, S. Clifford, J. Cioslowski, B. B. Stefanov, G. Liu, A. Liashenko, P. Piskorz, I. Komaromi, R. L. Martin, D. J. Fox, T. Keith, M. A. Al-Laham, C. Y. Peng, A. Nanayakkara, M. Challacombe, P. M. W. Gill, B. Johnson, W. Chen, M. W. Wong, C. Gonzalez, and J. A. Pople, Gaussian, Inc., Wallingford CT, 2004.

14- J.M.L. Martin, C. Van Alsenoy, program GAR2PED, University of Antwerp, 2011.

15- R. W. Hoffman, K. Menzel, Eur. J. Org. Chem., 2001, 1865.

16- E. Koglin; R. J Meier,.Chem. Phys. Lett., 1999, 312,284

17- J. Miao, S. Hua, S. Li, Chemical Physics Lett., 2012, 541, 7-11.

18- Y. Zhao, D.G. Truhlar, Theor. Chem. Acc., 2008, 120, 215.

19- W.A. Herrebout, B.J. van der Veken, A. Wang, J.R. Durig, J. Phys. Chem., 1995, 99, 578.

20- M.A. Murko, H. Castejon, K.B. Wiberg, J. Phys. Chem., 1996, 100, 16162.

21- G.D. Smith, R.J. Jaffe, J. Phys. Chem. 1996, 100, 18718 .

22- N.L. Allinger, J.T. Fermann, W.D. Allen, H.F. Schaefer III, J. Chem. Phys., 1997, 106, 5143.

23- M. J. Hafezi, F. Sharif, J. Mol. Structure Theochem, 2007, 814, Issues 1-3, 43. 